\title{
A SOBERANIA DO ECONÔMICO NAS REFLEXÕES DE HANNAH ARENDT E ZYGMUNT BAUMAN $^{1}$
}

Cícero Silva Oliveira (PUC-RJ $)^{2}$

cicerojosinaldo@gmail.com

Resumo: Sob o amparo das reflexões de Hannah Arendt e Zygmunt Bauman, o presente texto sustenta que a incorporação da esfera pública pela economia de consumo, que dá origem a uma política de agenda e cooperação econômicas, constitui a condição, o ponto de apoio e a extensão do consumo, inicialmente circunscrito ao âmbito econômico, à conduta modelo abrangente do sistema social. Assim, a despeito da diversidade de fenômenos de destaque implicados no problema do consumo - uma questão decisiva para a feição característica do nosso tempo -, sublinhamos que as verdadeiras causas da abrangência deste evento estão enraizadas na profunda transformação do espaço público e que, de maneira geral, sua agora franca extensão se sustenta no modo peculiar como a sociedade moderna opera desde então.

Palavras-chave: economia; soberania; Hannah Arendt; Zygmunt Bauman.

A história da modernidade pode, de fato, ser contada como a história da progressiva emancipação do trabalho, a saber, a vitória da atividade que prepara as coisas para o consumo sobre as atividades da obra e da ação, deflagrando, com isso, uma economia e uma organização "política” análogas. Nesse caso, o imperativo de consumo é a própria instituci-

\footnotetext{
${ }^{1}$ Recebido: 18-03-2013/Aprovado: 30-06-2013/Publicado on-line: 29-09-2013.

${ }^{2}$ Cícero Silva Oliveira é Doutorando na Pontifícia Universidade Católica do Rio de Janeiro, Rio de Janeiro, RJ, Brasil.
} 
onalização da lógica do trabalho ou da vida na economia, e o caráter especialmente econômico da esfera pública moderna sua mais flagrante implicação política. À Hannah Arendt interessava demonstrar, "por um lado, a redução contemporânea do humano a um animal que trabalha, e, por outro, a transformação da política na gestão administrativa daqueles dois interesses privados privilegiados, produzir e consumir" (DUARTE 2010, 318).

Mas só a recente consolidação da sociedade de consumidores, condicionada por aquele duplo processo e pelos eventos históricos que lhe são inerentes, pôde instituir a soberania da ordem econômica. Por isso, o que chamamos de sociedade de consumidores constitui, em sentido estrito, um arranjo social, um tipo novo e específico de socialização, que foi sendo progressivamente moldado à imagem e semelhança dos mercados de consumo por seus princípios de estruturação.

A expressão refere-se, assim, a um modo de socialização que, dessa forma, já é em si mesmo um registro da sobreposição da ordem econômica a âmbitos que, se não estavam completamente isentos de sua influência, também não se deixavam ser amplamente moldados e reconfigurados pelo econômico. Foi como economia de consumo desencadeada pela emancipação do trabalho que o econômico, mediante subordinação e exercício de soberania entre os subsistemas sociais (a começar pela conquista do político), plasmou o consumo num modo de vida em sentido pleno, alçando-o à esfera pública e, logo depois, à condição atual de um dos princípios de inteligibilidade elementares do sistema social.

É verdade que os vínculos humanos remanescentes, isto é, de natureza não econômica, sofreram o primeiro grande abalo quando a esfera pública foi agenciada pelos interesses 
privados da sociedade, no fenômeno moderno que Arendt conceituou como "advento do social". A expressão se refere, dessa forma, à nova situação moderna em que, admitidos na agenda pública, os interesses privados atinentes à sobrevivência e ao processo de aquisição alteraram não apenas a agenda dos assuntos públicos, mas a própria natureza da política.

No contexto das reflexões arendtianas, o "domínio social" é a denominação para o fato de que a admissão moderna dos interesses privados no domínio dos assuntos públicos turvou a antiga fronteira que separava as esferas privada e pública da existência; as demandas da vida das condições de exercício da liberdade. A eclosão do social, a "esfera pública" característica da era moderna, indica assim o alargamento do âmbito das necessidades que atendem ao processo biológico às expensas da política.

Com o domínio social o processo biológico humano estabelece então o "domínio público" no qual o cidadão se define mais como sujeito de demandas sociais do que como agente político de outrora. Daí que o domínio social, a "politização" de questões privadas relativas ao processo vital, seja a mais flagrante manifestação da vitória dos aspectos vitais na esfera pública; a vitória do trabalho sobre a ação. Sua expressão formal é uma implicação, um enredamento do biológico sobre o poder político na figura exclusiva de demandas sociais. Trata-se, assim, da anexação empreendida pelo animal laboras de um domínio autônomo e em princípio erigido contra o elemento invasor agora vitorioso.

A fórmula enigmática com que Arendt descreve esse fenômeno, "crescimento não natural do natural", expressa a transformação do cidadão no "animal laborans, o ser vivo entregue às atividades conexas de trabalhar e consumir, as 
quais se transformaram [também] no elemento central da relação política” (DUARTE 2010, 314). Essa organização pública do processo vital, que determina o estatuto biológico da esfera pública, aloca o animal laborans ao centro da política moderna. Trata-se, em última análise, de uma espécie de naturalização do homem por meio da naturalização de um modo de vida em comum que, desde os gregos, somente ele (um ser vivo dotado de fala) poderia ter.

As raízes históricas desse estatuto biológico da política moderna, no qual a nação foi concebida à imagem e semelhança de uma grande família de proporções nacionais, cujos interesses vitais são representados pela administração das demandas domésticas coletivizadas (o Estado-nação), remontam à tradição jusnaturalista em sua vertente laica. Esta, por sua vez, nasceu do grande desafio teórico a que a modernidade política, desde Hugo Grócio, foi confrontada na ocasião em que a suposta sanção religiosa (que servira durante o período medievo como princípio de legitimidade absoluto do direito político) entrou em crise.

Sem dúvida era enorme a importância da sanção religiosa nos assuntos políticos. Um dos problemas que o seu colapso suscitou traduzia-se em encontrar outro princípio absoluto, embora não transcendente, capaz de fundamentar, legitimar, expor as razões de ser e a finalidade da instituição do poder político nas relações humanas.

Essa ascensão do secularismo, consequência da separação entre Estado e Igreja, e as perplexidades que lhe são paralelas, engendrariam uma perspectiva político-filosófica decisiva para a compreensão da noção de direitos humanos naturais, mas também para a da organização política que começa a caracterizar a Europa após a Revolução Francesa e a institucionalizar os traços biológicos da política moderna: 
o sistema de Estados-nações.

Com base na premissa de que o simples ato de nascer investe de direitos os recém-chegados ao mundo, o jusnaturalismo ou a teoria laica do direito natural, na contramão da antiga tradição política, concebeu os direitos não como o resultado de artifícios da ação humana e da organização política, mas como prerrogativas naturais ou direitos prépolíticos, que para além de simplesmente evidenciar os limites do poder governamental legítimo, se apresenta como seu fundamento, isto é, justifica sua validade. Esse ponto de vista jurídico e filosófico, defendido de Grócio à Rousseau, começa a reivindicar, e a efetivamente ganhar espaço histórico, na ocasião da Revolução Francesa, quando é proclamada a Declaração dos Direitos do Homem sob a alegação de que, por decorrerem da natureza do mesmo, tais direitos são inalienáveis, não necessitando de qualquer tipo de autoridade para estabelecê-los.

Os traços históricos da asserção dos direitos humanos, que em última análise são os direitos naturais, ganham contornos ainda mais claros com o surgimento do chamado Estado-nação, enquanto organização política que se difunde pela comunidade dos países europeus. Sua flagrante relação com a postulação dos direitos humanos naturais se mostra em sua denominação.

O termo nação tem origem na palavra latina natio, particípio do verbo nascor, que significa nascer. No entanto, o Estado-nação e os direitos humanos têm como denominador comum o fato de que o nascimento ou o aparecimento dos homens no mundo é idêntico ao surgimento de personalidades jurídicas no mesmo (LAFER 2001). Daí que pela proclamação dos direitos humanos afirma-se um domínio jurídico que por desconhecer quaisquer tipos de distinções 
ou fronteiras é dito universal e abrange, por isso, um âmbito de vigência tão amplo quanto o mundo no qual os homens se movem.

Já a ideia de Estado-nação circunscreve um espaço no qual a organização política ou a comunidade de homens a ela pertencente é determinada com base nos critérios de terra e sangue. São nacionais os que participam da comunidade de sangue pertencente a um determinado território. Dessa forma, a nacionalidade não é apenas algo pressuposto na cidadania, mas antes lhe é correlata, porque é o vínculo político-jurídico estabelecido entre o nacional e a organização política consoante àqueles critérios que oficialmente lhe conferem direitos tutelados pelo Estado.

A ascensão do animal laborans à esfera pública é em todo caso favorecida pelo processo moderno de secularização a que o sistema político de Estados-nações em última análise se prende. Seu termo intermediário é a postulação de um sistema jurídico cujos direitos, que fundamentam o domínio político, são da ordem daquilo que é dado, isto é, natural. Os sectários dos direitos humanos conceberam a personalidade jurídica, e com ela a própria comunidade política, em termos de natureza, uma vez que os critérios de terra e sangue fazem coincidir as delimitações étnicas e políticas, a saber, supõem a cidadania como um dado natural, e não um resultado da ação humana, o que de per si faz do Estado-nação o registro da transformação pela qual o domínio político foi naturalizado.

O decisivo é que, ainda no contexto do Estado-nação, o arremate da naturalização do político se deva ao fato de que desde então "vemos o corpo de povos e comunidades políticas como uma família, cujos assuntos diários devem ser zelados por uma gigantesca administração doméstica de 
âmbito nacional”. De sorte que o que chamamos de sociedade é o "conjunto de famílias economicamente organizadas de modo a constituírem o fac-símile de uma única família sobre-humana, e sua forma política de organização é denominada 'nação”" (ARENDT 2010, 34).

O Estado-nação caracteriza assim a compreensão genuinamente moderna, e pretensamente axiomática, de que a política existe em função da sociedade organizada à imagem da família. Ele é a institucionalização da forma política pela qual a promoção do trabalho chega oficialmente à estatura de coisa pública, não obstante, de acordo com o pensamento grego concebido à luz do fenômeno político originário, a forma política de organização tenha sido forjada em completa oposição à organização natural da família e de suas demandas elementares relativas ao processo biológico.

O critério crucial com que os gregos concebiam duas ordens elementares de atividades humanas - de um lado as atinentes à manutenção da vida e de outro as relativas a um mundo comum -, era a distinção estre as esferas privada e pública da existência. Portanto, ao olhar retrospectivo, situado num cenário histórico em que o econômico ocupa cada vez mais o grosso da agenda política, é de fato altamente significativo que o equacionamento entre as esferas política e social, pública e privada (antes respectivamente correspondentes aos domínios da família e da política), seja um fenômeno caracteristicamente moderno, cuja expressão política é o Estado-nação. Essa compreensão da política como uma função da sociedade envolve a implicação fundamental de questões antes privadas da sobrevivência, do consumo e da aquisição transformarem em interesse coletivo, no sentido peculiar à modernidade, questões políticas de primeira ordem. 
O deslocamento de princípios-guia da esfera privada à pública, pelo advento de uma esfera híbrida como a social, é, desse modo, o solo em que se enraíza a vocação eminentemente econômica da política moderna, notadamente orientada pela gestão de demandas sociais, pelas quais as atividades conexas de trabalhar e consumir de algum modo encontraram guarida na esfera pública. Convém recordar a análise arendtiana segundo a qual este fato resulta num agravo à indistinção das atividades humanas fundamentais em favor do trabalho, já em curso desde o momento em que o trabalho como forma de produção industrial, guiado pelos ideais de abundância, consumo e reprodução da riqueza social (hoje aferida como crescimento do consumo), tragou a atividade da obra orientada pelo ideal de permanência. De modo que o diagnóstico arendtiano, a vitória do animal laborans ou da mentalidade consumidora, expressa não apenas o triunfo da vida sobre a economia, doravante cada vez mais alijada da atividade da obra, mas também sobre a política; a primeira "instituição" de natureza não econômica agenciada pela economia de consumo.

Este é seguramente o duplo e mais profundo significado da emancipação do trabalho no pensamento de Hannah Arendt. Seu registro já supõe o primeiro ato do que hoje, diante do que se revelou uma série ininterrupta de anexações bem-sucedidas, podemos caracterizar como uma espécie de soberania com que a economia de consumo remodela diversos setores da vida social e faz do próprio consumo o elemento descritor dos traços mais característicos das sociedades hodiernas.

Portanto, devemos ainda à Hannah Arendt a compreensão do aspecto viral da economia de consumo, a saber, de sua propensão a se expandir pelo sistema social. Para ela, o 
surgimento do domínio social, a primeira anexação do econômico pela qual o processo da vida criou o seu próprio domínio público, desencadeou um crescimento artificial do natural, o mesmo que se expressa tanto no aumento sempre crescente da produtividade do trabalho industrial, em consequência da qual todas as coisas têm de ser devoradas (já que o consumo mudado em imperativo econômico é única medida capaz de sustentar o processo de trabalho), quanto na naturalização do político, dada a afinidade de seu caráter acima de tudo econômico com o processo biológico da sociedade, isto é, a promoção do trabalho à estatura de coisa pública.

A rigor, este espraiamento da mentalidade consumidora em direção à esfera pública é o evento histórico que harmoniza e acomoda o domínio político ao processo de naturalização do homem, potencializado pela estratégia econômica de fazer do trabalho industrial a forma privilegiada de reprodução capitalista da riqueza. A economia de consumo, na medida em que impele força extraordinária àquele processo moderno de naturalização (implícita no alargamento ou na artificialização do metabolismo humano com as coisas), foi seguramente decisiva para o fato de que conferimos estatuto de ideal político inquestionável às aspirações do animal laborans, mais precisamente ao "contentamento básico que sempre abençoou a vida terrena" (ARENDT 2010, 133). Foram os traços caracteristicamente econômicos da esfera pública moderna, fruto do novo domínio social, que alçaram à dignidade de ideal político a realidade elementar de uma humanidade trabalhadora, esvaziando de sentido os antigos ideais de liberdade e permanência pelos quais a política resultava numa certa arte de cuidado com o mundo público, o mundo que temos em 
comum.

A fenomenologia arendtiana das atividades humanas fundamentais nos permite compreender que uma economia de consumo, nascida da emancipação do trabalho e independente de qual seja sua zona de influência no mundo humano, sempre carrega e difunde consigo os germes do metabolismo e do crescimento espontâneos inerentes ao processo vital a que o trabalho remete. A instabilidade do mundo humano presidido pela economia de consumo decorre do fato de que uma vez liberadas da esfera privada onde antes estiveram relegadas e mantidas dentro do movimento circular de exaustão e regeneração (sob a regulação do processo natural de nascimento e declínio), a atividade do trabalho e o metabolismo a que ela atende desencadearam no mundo humano uma forma inusitada e irrefreável do crescimento inerente a toda vida orgânica.

Nesse aspecto, o peculiar é que num ambiente estranho e isento dos mecanismos naturais de controle que o mantinha adstrito em seu lar natural, o processo orgânico do animal humano liberou no mundo aquele crescimento irrestrito contra o qual um mundo habitado por consumidores é em todo caso incapaz de opor obstáculos. Em tais condições, as atividades humanas provocadas pela necessidade de fazer face aos processos biológicos, paradoxalmente, incrementam e volteiam no movimento infinitamente repetitivo da natureza (o que dizer de sociedades nas quais a crise ecológica desencadeada pelo consumismo retroalimenta os discursos que induzem o consumo? Quando quotas internacionais de emissão de $\mathrm{CO}_{2}$ se tornam objetos de consumo negociados entre países produtores?).

Aquele crescimento não natural do natural teve início quando o metabolismo humano foi artificialmente alargado 
pela economia de consumo, quando a necessidade de devorar passou a ser uma relação crescente em relação às coisas. Mas a primeira grande anexação, que, como Arendt soube notar, foi igualmente decisiva para as subsequentes propagações da ordem econômica consumista, adveio quando o processo vital da sociedade foi elevado à estatura de assunto público. Quando a política passou a ser "regida exclusivamente pela lógica econômica do trabalho e do consumo" (DUARTE 2010, 321), que canalizou e estabeleceu a economia, os assuntos concernentes ao processo da vida, no centro da esfera pública.

Contudo, o cenário histórico em que o econômico ocupa cada vez mais o grosso da agenda política é na verdade o primeiro capítulo da história da sobreposição da ordem econômica sobre a esfera pública, cujo desfecho, ao que tudo indica, se está longe de conhecer. De qualquer forma, seu segundo capítulo, ainda em fase de redação, pode muito bem ter por título aquela espécie de processo de divórcio que, por intervenção da ordem econômica consumista e dos poderes globais por ela engendrada, Bauman diagnosticou entre poder e política ${ }^{3}$, em função da expropriação pela qual a própria agenda de opções da esfera pública é agora estabelecida por outro agente operacional essencialmente não político.

Partindo da consideração das condições gerais em que as escolhas individuais são feitas, Bauman identificou duas ordens de restrições a que tais opções individuais estiveram tradicionalmente circunscritas na modernidade, para que a liberdade individual de escolha, a chamada liberdade nega-

\footnotetext{
3 "Poder e política, que viviam unidos, estão separados e prontos para o divórcio. Só nos restam políticas cada vez mais impotentes e poderes cada vez mais politicamente descontrolados” (BAUMAN 2010a, 76-77).
} 
tiva do Estado moderno, fosse exercida dentro dos limites indispensáveis ao convívio social.

Assim, o primeiro conjunto de restrições inerente ao processo de escolha é dado pelo estabelecimento da agenda de opções, em que cada comunidade política moderna define "o conjunto de alternativas efetivamente disponíveis" às escolhas individuais (BAUMAN 2000, 79), de sorte que apenas em circunstâncias excepcionais o conjunto das próprias escolhas depende de quem escolhe. A forma histórica que este princípio formal (agenda de opções) recebeu na modernidade clássica foi a legislação, que, medida do ponto de vista do sujeito na condição de optante, exercia o poder político de pré-selecionar, isto é, estabelecer via atividade político-legislativa o conjunto de escolhas possíveis.

Situados naquelas condições extraordinárias do processo de escolha (nas quais raramente é possível delimitar o conjunto de opções), os legisladores reduzem o leque de opções individuais pela associação de escolhas e práticas socialmente indesejáveis a sanções punitivas rigorosas o suficiente para desencorajá-las. Ao longo da modernidade, a legislação estabelece a agenda de opções na medida em que divide as opções que são em princípio possíveis, embora não desejáveis, das que são permitidas e proibidas, sendo por isso mesmo puníveis.

Já o segundo conjunto de restrições é formalmente definido pelo código de escolha, que, independente do conteúdo histórico, assume sempre o aspecto de "regras que indicam com base em quê se deve preferir uma coisa a outras e quando a escolha é adequada ou não". O código de escolha predominante no mundo moderno foi a educação. Por ela a modernidade despendeu e institucionalizou a maior parte do esforço de orientar os indivíduos optantes a 
exercer a liberdade segundo a agenda estabelecida pelo poder político legislativo. Seu papel consiste em fornecer sinais seguros de orientação preciosos à vida em sociedade, em arraigar princípios ou valores de conduta capazes de recobrir e guiar a escolha, dotando simultaneamente os optantes da capacidade e da inclinação para identificar e seguir as razões corretas e evitar as contrárias. A educação tem em vista a internalização dos valores codificantes pelos quais a agenda de opções "disponíveis/permitidas" (estabelecida pelo dispositivo político-legislativo) é convertia em "desejáveis/recomendáveis/adequadas" e "indesejáveis/ não recomendáveis/inadequadas" (BAUMAN 2000, 79).

A legislação é a esfera de restrição das opções, a agenda de opções ou a pré-escolha política, ocupada com a normatividade das ações, ao passo que a educação é o âmbito em que a restrição das opções de escolha pretende atingir, via normas ou códigos de escolha, as disposições dos optantes, em vista do acordo ou do ajustamento entre liberdade e legislação, escolha individual e interesse sociopolítico. A formação educacional é a ponte estendida entre os recémchegados ao mundo e as condições em que a vida humana é partilhada no mundo que os precede, no mundo que existia antes de nele chegarem ${ }^{4}$.

Para Bauman, a particularidade das instituições públi-

\footnotetext{
${ }^{4}$ Também Arendt apresenta uma noção semelhante da relação entre educação e vida pública: "Normalmente a criança é introduzida ao mundo pela primeira vez através da escola. No entanto, a escola não é de modo algum o mundo e não deve fingir sê-lo; ela é, em vez disso, a instituição que interpomos entre o domínio privado do lar e o mundo com o fito de fazer com que seja possível a transição, de alguma forma, da família para o mundo. Aqui, o comparecimento não é exigido pela família, e sim pelo Estado, isto é, o mundo público, e assim, em relação à criança, a escola representa em certo sentido o mundo, embora não seja ainda o mundo de fato. Nessa etapa da educação, sem dúvida, os adultos assumem mais uma vez uma responsabilidade pela criança, só que, agora, essa não é tanto a responsabilidade pelo bem-estar vital de uma coisa em crescimento como por aquilo que geralmente denominamos de livre desenvolvimento de qualidades e talentos pessoais. Isto, do ponto de vista geral e essencial, é a singularidade que distingue cada ser humano de todos os demais, a qualidade em virtude da qual ele não é apenas um forasteiro no mundo, mas alguma coisa que jamais esteve aí antes." (ARENDT 2005, 238-239).
} 
cas vigentes é que, de forma implícita ou explícita, de maneira clara ou velada, dão livre curso a um processo de renúncia, ou pelo menos de redução do que originalmente era sua dupla função de estabelecer a agenda e o código de escolha. Isso em princípio poderia figurar como uma extensão do campo da liberdade negativa, não fosse pelo fato de que outro agente operacional tem aos poucos feito recuar e arrogado para si o estabelecimento da agenda e do código de opções antes constituídos politicamente.

$\mathrm{Na}$ verdade este recuo das forças políticas, que em termos de exigência de mercado foi chamado de "desregulamentação”, visa diminuir apenas o papel regulador do Estado, mas de modo algum advoga pelo fim da regulamentação. Por uma espécie de autolimitação, empreendida em vista das pressões de mercado, mais do que operar uma política de agenda eminentemente econômica, o Estado aos poucos transfere o papel de estabelecer a agenda de opções a forças essencialmente não políticas, especialmente aquelas integradas aos mercados financeiros e de consumo ${ }^{5}$.

Nesse caso, o processo de desregulamentação, com seu sentido estritamente político, implica hoje numa não menos severa exposição dos indivíduos optantes tanto à força coercitiva (agenda) quanto ao poder doutrinador (código)

\footnotetext{
${ }^{5}$ Em análise às "mudanças estruturais" exigidas por analistas econômicos do setor privado para "maiores ganhos de produção”, quando onze dos dezesseis integrantes da União Europeia estabeleceram o acordo de instituição de uma moeda em comum, Alan Friedman observou que "mudança estrutural" é na verdade "a expressão em código para maior facilidade de contratação e demissão, para redução dos gastos públicos com aposentadorias, pensões e benefícios sociais e para a diminuição dos elevados encargos sociais e contribuições das empresas na Europa Ocidental.” (FRIEDMAN 1998 apud BAUMAN 2000, 32). Ainda, “[...] em reposta à grave crise econômica nos países do Extremo Oriente o Fundo Monetário Internacional veio com sua receita padrão [tentada anteriormente no México com resultados bem pouco atraentes]: demissões, taxas de juros mais altas e abertura dos mercados locais ao investimento estrangeiro. [....] Numa entrevista concedida a Babette Stern, do Le monde, o diretor geral do FMI, Michel Camdessus, confirma as intenções que os economistas atribuem à instituição que ele comanda e as define como uma estão de orgulho: "a liberação sistemática dos movimentos de capital', diz Camdessus, 'deve ser a nova missão do FMI'." (BAUMAN 2000, 32) (grifos nossos).
} 
do verdadeiro poder não político que estipula o horizonte de opções dadas. De modo que a agenda de opções mais importante dificilmente pode ser construída politicamente nas atuais condições. A despeito do recuo do Estado existe uma agenda de opções que não se torna menos coercitiva ou regulamentada por não ser estabelecida politicamente.

Por isso, a tendência de divórcio ente poder e política se refere ao fato capital de que nas condições atuais as instituições políticas, eleitas e em princípio controladas pelo povo, não constituem de modo algum a única (nem talvez a principal) força capaz de decidir a extensão das decisões práticas. $\mathrm{O}$ estabelecimento da agenda conta hoje com um novo agente operacional; um agente que já figurava em papel secundário, mas que agora se antepôs às instituições políticas, que cada vez mais desempenham aquele papel secundário a que as pressões de mercado estavam antes relegadas. Daí que para Bauman essas pressões estejam progressivamente substituindo a legislação política em seu poder de estabelecer a agenda de opções e galgando com isso uma posição estratégica para o que um ex-diretor do Fundo Monetário Internacional chamou de "liberação sistemática dos movimentos de capital”, que ele admitiu ser a nova meta de tal instituição.

O mais obstinado testemunho da separação entre poder e política referida por Bauman é aquela espécie de automatismo com que a esfera econômica, por si só, cristaliza a agenda de opções. Em flagrante oposição à ação dos operadores políticos, a agenda estabelecida pelas pressões de mercado resulta hoje não de uma ação propositada precedida por certa motivação e articulada por um objetivo, mas do livre jogo das forças de mercado e dos pós-efeitos que delas resultam. A atividade agendadora não mais se guia pelos 
critérios de racionalidade da ação com que as instituição políticas modernas foram constituídas.

Apesar de concernir à ação prática dos indivíduos, a atividade agendadora tem hoje aquele estranho aspecto de produto natural (que Arendt já havia antecipado quando identificou um processo de naturalização do domínio político moderno), marcado pela independência da vontade e da intenção dos próprios agendadores - que dirá dos optantes finais. Seu modelo operacional, radicalmente distinto do modelo político que o precede, é a-racional. Portanto nem racional nem irracional. $O$ que significa que não se orienta pelos princípios racionais e nem tampouco se insurge conta eles. Essa agenda de opções "simplesmente é, assim como as serras e os mares são - aparência muitas vezes endossada na frase preferida dos políticos: 'não há alternativa"” (BAUMAN 2000, 81).

Vista da perspectiva do mecanismo político de agendamento e dos indivíduos a que por fim ela se destina, a agenda de opções literalmente brota, pulula da dinâmica econômica ritmada pelos mercados de consumo e financiamento, por seus estímulos internos ou externos, independentemente, em todo caso, da vontade e da consciência dos "agendadores" e optantes. Enquanto produto das forças de mercado, a agenda de opções é sempre algo contingente. Não resulta de qualquer planejamento, e, embora seja por isso fortuita e casual quando observada isoladamente, em nosso cenário é politicamente concebida como necessária e inevitável ao ser relacionada às causas econômicas que lhe deram origem.

Com efeito, é como evento forçoso que de nenhum modo se pode evitar (como alguma ocorrência incontornável para qual "não há alternativa" política) que as questões 
econômicas se antepõem e subordinam o processo político no estabelecimento da agenda de opções. E essa "fatalidade" pela qual a agenda de opções não poderia ser diferente do que é, a saber, do que o livre jogo das forças de mercado fortuitamente impõe, determina no nosso tempo um novo trâmite supralesgislativo à atividade agendadora. Em última instância legitimado pela inevitabilidade dos fenômenos econômicos, que no fim das contas se traduzem em imperativos políticos contra os quais, assim como as tsunamis ou terremotos, não faz sentido protestar ${ }^{6}$.

E este é o ponto em que o ciclo se fecha: não há argumento político, num mundo habitado por consumidores, que resista à ameaça de ruína econômica sinalizada pela recessão, isto é, pela redução do consumo. Mesmo quando a atividade agendadora implique uma forma politicamente não soberana ou heterônoma (porque economicamente necessária) de agendamento das opções.

Admitida como inevitável, a imediata conversão das necessidades econômicas da vida social em imperativos políticos, agora também à revelia de seus processos, é, aliás, a mais recente e vigorosa expressão da promoção do trabalho ou da vida à estatura de coisa pública. Ou ainda, numa expressão inversa, mas semanticamente idêntica: o expediente pelo qual se completa a regência da esfera pública pela lógica econômica do trabalho/consumo; a subordinação dos dispositivos políticos pelos processos econômicos. Ao seguirmos o pensamento de Hannah Arendt, percebemos que

\footnotetext{
6 "Ser esmurrado por ondas poderosas, arrastado por ventos tremendos que sopram de lugares distantes e chegar sem aviso é uma situação exatamente oposta à de cidadania. Os súbitos altos e baixos na sorte coletiva adquirem hoje uma extraordinária semelhança com as catástrofes naturais, embora mesmo essa comparação pareça cada vez mais um atenuante: acontece que temos hoje em dia melhores condições de prever um terremoto iminente ou a aproximação de um furacão do que a próxima quebra da bolsa de valores ou a evaporação de setores aparentemente seguros para o emprego de massa.” (BAUMAN 2000, 172-173)
} 
essa sobreposição da ordem econômica sobre a política é na verdade um alastramento das funções biológicas sobre o artifício humano, uma vez que está orientada pelos princípios conexos de consumo, necessidade e atenção exclusiva ao processo vital da espécie, cristalizados nos imperativos essencialmente não políticos (os imperativos econômicos) que hoje moldam a agenda de opções e determinam o caráter da esfera pública.

O processo de divórcio entre poder e política é, assim, o mais recente desdobramento da fertilidade natural ou da extensão automática da (até agora não refreada) lógica vital liberada no mundo humano. Desse modo, a vitória parcial dos argumentos econômicos em favor da liberação sistemática dos movimentos do capital e das finanças, conquistada por seu agente político, o neoliberalismo, apenas reforça e fomenta os fatos já apontados por Arendt quando repele "todas as tentativas de frear ou regular os seus movimentos", alegando não ser "uma opção política dentre outras, mas um ditame", uma necessidade imperiosa (BAUMAN 2000, 35). Seguramente não é outra a razão de Pierre Bourdieu haver definido as teorias e práticas neoliberais como um programa para destruir as estruturas coletivas capazes de resistir à lógica do 'mercado puro'.

Ainda que travestidos pelo manto imaculado da "adequação aos princípios racionais”, esses argumentos se inscrevem no quadro geral do movimento de naturalização, no curso do qual os assuntos mundanos são confiados não às decisões de agentes políticos, mas a processos econômicos contingentes e imprevisíveis com os quais o processo da vida, sob o signo da necessidade, já há algum tempo se estende compulsoriamente ao mundo. A eliminação de impedimentos políticos para o crescimento da riqueza soci- 
al via consumo é uma das sendas privilegiadas pelas quais o processo da vida amplia seus domínios no artifício humano. Em última análise, a vitória do econômico implica a subordinação da política ao ciclo vital em nome da abundância, que como ideal mina a permanência e durabilidade mundanas.

A separação entre poder e política é, assim, um fenômeno emergente que se manifesta nas pressões contínuas com que o mercado abala a racionalidade política de qualquer alternativa às opções que ele oferece. Essa inevitabilidade política, que sob pena de ruína traduz as opções do mercado em imperativos econômicos, remonta à constituição dos poderes globais; os poderes realmente poderosos que, de acordo com Bauman, ao contrário do caráter local do poder político, são hoje fundamentalmente extraterritoriais.

Daí que a globalização do capital, das finanças e da informação seja apenas outro nome com que a separação entre poder e política pode ser referida. Graças aos poderes globais, "os parâmetros mais decisivos da condição humana são agora forjados em áreas que as instituições do Estadonação não podem alcançar" (BAUMAN 2000, 172). Isso a julgar que os poderes mais determinantes para a manutenção e mudança de tais condições são cada vez mais globalizados, ao passo que os meios de controle e intervenção do empenho político, independente do quanto possam ser poderosos, permanecem restritos a níveis territoriais nos quais dificilmente hoje (em condições globalizadas) podem atingir os limites da soberania?.

\footnotetext{
7 "Assim como o usuário da web mundial só pode escolher dentre as opções oferecidas e dificilmente pode influenciar as regras pelas quais a Internet opera ou a gama de opções disponíveis dentro das regras, da mesma forma as nações-estados individuais lançadas num ambiente globalizado têm que jogar o jogo segunCont.
} 
Em todo caso, a incorporação definitiva da política pela ordem econômica, em virtude da qual com automatismo e naturalidade inauditas as necessidades econômicas são agora imediata e legitimamente traduzidas em imperativos políticos, apenas retira o derradeiro obstáculo político (a soberania) para o incremento daquela forma anômala e incontrolável de crescimento da vida deflagrada quando de sua liberação no mundo humano ${ }^{8}$.

Não por acaso, Arendt identificou a naturalização do homem e das relações políticas com o processo moderno de reprodução da riqueza social, já que o ideal capitalista de abundância, pelo qual esta reprodução desde então tem sido operada, reduziu as atividades produtivas à lógica vital do trabalho/consumo, que logo em seguida foi igualmente introduzida na esfera pública pelas funções prioritariamente econômicas da política moderna. A separação entre poder e política, referida por Zygmunt Bauman, nos reporta finalmente à expropriação econômica do poder político de determinar a agenda de opções, em todo caso já econômica. Assim, o fato de que a própria agenda de opções é, de algum modo, determinada pelos mercados de consumo e finanças sela a vitória dessa economia sobre a política e

\footnotetext{
do as suas regras e arriscar-se, caso ignorem as regras, há um severo troco ou, na melhor das hipóteses, à total ineficácia dos seus empreendimentos. Para encurtar a história, basta dizer que enquanto o Estado é o único agente legislativo capaz de empreender [por exemplo,] a adoção de um salário básico [aos cidadãos em dificuldades econômicas], ele é ao mesmo tempo singularmente incapaz de fazê-lo por si mesmo" (BAUMAN 2000, 193). A ausência de controle, o aspecto espontâneo, não planejado e imprevisto da política de regência econômica (de incontornável semelhança com um produto natural) é, para Bauman (2000, 193), a marca característica com que a Globalização "assinala uma naturalização sui generis do curso que os assuntos do mundo estão tomando".

${ }^{8} \mathrm{O}$ processo sem precedentes de naturalização do homem subjacente à promoção do animal laborans, tal como ele se manifesta na economia de consumo e na politica de agenda econômica, configuram, nas palavras de André Duarte (2010, 314), "a chave a partir da qual se constitui a pertinência de falar-se em biopolitica [politização da vida biológica] no pensamento arendtiano, a despeito da ausência do próprio conceito". ( $\mathrm{O}$ autor aventa ainda a possibilidade de no ensaio Sobre a violência Arendt ter, em alguma mediada, antecipado a tese de Foucault de que a biopolítica supõe uma tanatopolítica: a política como dispositivo de incremento da vida supõe a violência para proteger a vida que merece viver da vida que não merecer viver.)
} 
completa um longo processo de incorporação e simultânea automatização ou perda de controle (o processo de naturalização), cujos primeiros registros encontramos na obra de Hannah Arendt.

O decisivo é que para além de completar a subordinação do político à economia de consumo, essa primeira anexação foi absolutamente determinante para a soberania da ordem econômica, a saber, a extensão prática ou formal da lógica consumista ao sistema social, expressiva o suficiente para constituir um modo de vida dominante (uma sociedade de consumidores).

É realmente crucial que por esta vitória primeira o cidadão tenha sido mais claramente equacionado a sujeito de demandas sociais em função do qual a política, mais do que instrumento de satisfação de necessidades coletivas, sob pena de sanções severas, passou também de algum modo a ser operada por regras econômicas extraterritoriais dependentes do acaso, conforme sustenta Bauman. No instante em que "o estado reconhece a prioridade e superioridade das leis do mercado sobre as leis da pólis, o cidadão transformase em consumidor - e o consumidor", por sua vez, "demanda mais e mais proteção enquanto aceita cada vez menos a necessidade de participar." (BAUMAN 2000, 159).

Portanto, se é verdade que, de um modo geral "a sociedade pós-moderna envolve seus membros primariamente em sua condição de consumidores” (BAUMAN 2001, 90), que a economia de consumo atualmente molda as condições gerais de interação social a ponto de estabelecer formalmente a relação de consumo como conduta modelo abrangente, vale dizer, sistemática nas sociedades contemporâneas, a política de agenda e cooperação econômicas deve constituir o seu mais decisivo ponto de partida. É nessa 
primeira subordinação empreendida pela ordem econômica consumista que, à luz das reflexões filosóficas de Hannah Arendt e Zygmunt Bauman, julgamos encontrar o fundamento para a ideia de sistema social de consumo, de ações socialmente coordenadas para a promoção do consumo como principal objetivo da vida.

Com efeito, o peso desse fenômeno sobre a série ainda em curso de anexações da ordem econômica consumista (do crescimento da vida a expensas do mundo) foi igualmente reconhecido por Hannah Arendt e Zygmunt Bauman. Respectivamente pelos diagnósticos que de um lado reconhecem a política de agenda fundamentalmente econômica como o resultado das profundas transformações do político na modernidade - desde o início marcado pela confusão entre privado e público -, e, por outro, identifica (como uma de suas mais recentes implicações) o mercado como um poderoso e inelutável agente operacional da esfera pública.

Mais do que simplesmente agenciada pelos interesses privados da sociedade, em última análise aqueles relativos ao processo vital de consumo e aquisição, a esfera pública foi realmente posta a serviço dos mercados de consumo e finanças, isto é, sujeitada às regras fortuitas constitutivas de sua dinâmica, pelas quais, desonerando o cidadão da participação política, pôde mais eficientemente assumir o permeio da satisfação e do fomento das crescentes demandas sociais a um só tempo suscitadas e atendidas pelo mercado. Se o primeiro evento marca o momento de justaposição do político ao ideal econômico de abundância, a saber, sua contiguidade ao processo (assim potencializado) de incremento da vida e da riqueza social pela multiplicação e satisfação de demandas politicamente coletivizadas, o segundo 
(a regência da política pelo mercado) certamente assinala a conjuntura crucial que hoje torna ainda mais difuso e tênue o que antes era um abismo situado entre o homem na condição de consumidor e o homem na condição de cidadão; entre o animal laborans e o agente político?.

Uma das mais originais contribuições do pensamento de Hannah Arendt, que nos auxilia na compreensão deste evento, foi ter demonstrado que na modernidade, pela primeira vez na tradição política ocidental, o homem foi admitido na esfera pública antes de tudo como vivente, isto é, como portador de demandas vitais orientado pelos princípios de saciedade e abundância. Esse fenômeno assinala para ela o domínio social; a politização dos fenômenos vitais da espécie com que o processo biológico humano funda um domínio público próprio, em plena oposição ao antigo ideal político de remissão da condição natural a que o homem, como todo criatura viva, está incontornavelmente circunscrito.

A organização pública do processo da vida em sentido social foi o expediente moderno que simultaneamente equacionou o cidadão àquele representante humano da condição natural da vida, enleado às atividades integradas de trabalhar e consumir (o animal laborans), e desencadeou, por meio da política, um crescimento irrefreável da própria

\footnotetext{
9 "O desaparecimento do abismo que os antigos tinham de transpor diariamente a fim de transcender o estreito domínio do lar e "ascender" ao domínio da política é um fenômeno essencialmente moderno. Esse abismo entre o privado e o público ainda existia de certa forma na Idade Média, embora houvesse perdido muito da sua importância e mudado inteiramente de localização. [...] A tensão medieval entre a treva da vida diária e o grandioso esplendor de tudo o que era sagrado, com a concomitante ascensão do secular ao religioso, corresponde em muitos aspectos à ascensão do privado ao público na Antiguidade. É claro que a diferença é muito marcante, pois, não importa quão "mundana" a Igreja tenha se tornado, o que mantinha reunida a comunidade dos crentes era essencialmente sempre uma preocupação extramundana. [...] Na raiz da consciência política grega encontramos uma clareza e uma precisão sem-par na definição dessa diferença [entre as esferas pública e privada]. Nenhuma atividade que servisse à mera finalidade de garantir o sustento do indivíduo, de somente alimentar o processo vital, era autorizada a adentrar o domínio político." (ARENDT 2010, 39/40/44)
} 
vida emancipada no mundo. Sua expressão mais recente é talvez a série de movimentos automáticos, aquela ausência de controle que a esfera econômica, pela expropriação do poder político de determinar a agenda de opções, deflagrou no domínio dos assuntos humanos, do qual já há bastante tempo (como Hannah Arendt soube demonstrar) a ação humana está cada vez mais ausente.

Por fim, não deve ser objeto de perplexidade o fato de que o mercado de consumo e finanças tenha de algum modo assumido a direção daquilo que, apesar da agenda econômica da esfera pública, ainda era assunto de decisão política. Ao contrário, que os poderes essencialmente não políticos do mercado tenham imediatamente seguido no encalço da ação, quando de sua evasão da esfera pública moderna, decorre da constituição dos eventos pertinentes ao processo econômico de apropriação, reconhecido por Arendt como um dos mais singulares eventos da modernidade capitalista. Isso no que tange, particularmente, às suas implicações políticas: a progressiva imediação da esfera pública ao processo econômico de reprodução da riqueza social, deflagrada no limiar da era moderna. A afinidade entre essa política de agenda econômica e o projeto moderno de multiplicação da riqueza social se deve ao fato de que, quando a saciedade é convertida em principal objetivo da vida política, é inevitável que a abundância (seu equivalente normativo) se torne o ideal político por excelência.

Quando o processo vital da espécie ganhou asilo político no mundo humano, o crescimento econômico via consumo, perseguido ao longo da era modera, encontrou novas e extraordinárias condições de incremento que foram realmente decisivas para o perfil das sociedades hodiernas. Nelas, um consumo alargado (como relação indiscriminada de 
metabolismo humano com as coisas) confere hoje livre curso ao processo de naturalização que, a título de necessidade econômica - a necessidade de devorar as coisas produzidas à maneira do processo interminável de trabalho -, mina a estabilidade do mundo ${ }^{10}$.

Associados a alguns dos eventos históricos mais decisivos para os traços característicos da esfera pública na modernidade (nomeadamente a confusão entre público e privado e a reabilitação da glorificação da vida em uma sociedade secular ${ }^{11}$ ), os poderes então emergentes do mercado, hoje poderes globais - em última análise aqueles ligados à economia de consumo deflagrada pela emancipação do trabalho -, atuaram e permaneceram à espreita das transformações que harmonizaram o político às novas condições econômicas de reprodução do capital. Quando o aspecto mundano do empenho político foi absorvido pelas deman-

\footnotetext{
10 “O princípio do 'waste' é o princípio econômico por excelência da sociedade industrial, a descoberta original dos Estados Unidos, a saber: se todas as coisas produzidas se fabricam melhor e mais depressa por meio do trabalho, têm também que ser tratadas como produtos do trabalho, quer dizer, não devem ser usadas, mas têm de ser consumidas, gastas. E isso somente pode ser logrado nas coisas por meio do 'waste'." (ARENDT apud DUARTE 2010, 317)

${ }^{11}$ A vitória do credo cristão entre a humanidade ocidental demarcou o momento a partir do qual a vida individual, dada como eterna pela primeira vez na história do Ocidente, passou de fato a ser concebida como o bem supremo para o homem. Esse princípio inviolável de origem cristã permaneceu insuspeito ao arsenal crítico da modernidade e foi finalmente reabilitado com a emancipação do trabalho ou com a vitória do animal laborans, que uma vez mais, embora num contexto secular que lhe deu outros contornos ainda mais danosos para o mundo, içou a vida no plano social (tal como ela se afirmou desde o surgimento da sociedade) ao centro das atenções humanas. $O$ decisivo nesse contexto é que a sacralidade da vida na era moderna, do mesmo modo que sua precedente cristã, implique necessariamente uma alienação do mundo comum e humano, cuja privação da além-mundanidade cristã (implícita no processo moderno de secularização), tendo esvaziado o sentido das esperanças escatológicas de um destino supraterreno, terminou por remeter o homem não de volta ao mundo, mas à interioridade fechada da introspecção, no interior da qual a qualidade objetiva das coisas e a mundanidade em sentido geral passaram, em última análise, a ser absorvidas pelo processo vital da espécie. Com a secularização moderna "a vida individual voltou a ser mortal, tão mortal quanto o fora na Antiguidade, e o mundo passou a ser ainda menos estável, menos permanente e, portanto, menos confiável do que o fora durante a era cristã. Ao perder a certeza de um mundo futuro, o homem moderno foi arremessado para dentro de si mesmo, e não para este mundo. [...] o homem moderno não ganhou este mundo ao perder o outro, e tampouco, a rigor, ganhou a vida; foi empurrado de volta para ela, arremessado na interioridade fechada da introspecção, na qual o máximo que ele poderia experienciar seriam os processos vazios do cálculo da mente, o jogo da mente consigo mesma" (ARENDT 2010, 400401).
} 
das sociais, a saber, pelos interesses elementares coletivizados de consumo e aquisição, o processo vital da espécie humana ou a condição do animal laborans foi politizada, dando origem à política de agenda econômica. Mas só a mais recente admissão política da prioridade das leis de mercado, a política de cooperação econômica, é que realmente transformou o cidadão em consumidor.

Pela constituição dos poderes globais, a globalização do capital e das finanças - graças a qual "os parâmetros mais decisivos da condição humana são agora forjados em áreas que as instituições do Estado-nação não podem alcançar" -, a economia de consumo se antepôs aos trâmites dos processos de decisão política através das pressões de mercado. Nesse caso, esse processo explícito de desintegração da soberania política em atenção à "liberação sistemática dos movimentos de capital" (que Michel Camdessus estipulou ser a nova missão do FMI) é, no fim das contas, uma nova e decisiva expressão daquele aspecto viral da economia de consumo, por meio do qual a vida liberada no mundo tende a um crescimento anômalo e incontrolado em relação ao modo como se processa no seio da natureza. Com essa vitória completa sobre o político, o aspecto devorador da vida (a princípio institucionalizado no econômico como expediente de ampliação da riqueza) oportunizou novas e extraordinárias condições de incremento com a dilatação do alcance social do consumo a outros domínios do sistema social, elevando a um novo plano a estratégia econômica da era moderna.

Quando as pressões de mercado agregaram força suficiente para desencadear o processo de substituição da legislação política no poder de estabelecer a agenda de opções, foi como se o econômico começasse a recusar a função mera- 
mente acessória que havia desempenhado no plano político desde a politização dos fenômenos vitais da sociedade. De sorte que aquele processo de divórcio entre poder e política já é indicativo da saída do econômico da posição subalterna em que as decisões políticas, a despeito da agenda econômica da esfera pública, eram confiadas exclusivamente ao poder legislativo segundo os trâmites consagrados pelo processo democrático moderno.

As crescentes intervenções supralegislativas em favor das quais as instituições políticas têm desde então recuado conferem cada vez mais à ordem econômica consumista o poder de decidir a extensão das decisões práticas. É justamente essa vitória do econômico sobre o político, a precedência política das leis de mercado sobre as próprias leis e instituições políticas, que finalmente convertem o cidadão em consumidor e fazem do estado um interposto, uma instituição mediadora da relação entre "cidadão" e mercado. Refletindo esse papel do Estado é natural que, como disse Bauman, o "consumidor demande mais e mais proteção enquanto aceita cada vez menos a necessidade de participar”.

Foi a partir destas condições, oriundas de profundas transformações na esfera pública, que o projeto moderno de inexorável crescimento econômico pôde encontrar aliados sem iguais no Estado e no cidadão da política de agenda e cooperação econômicas. Aquele novo agente operacional da esfera pública criou assim os meios para a série bem-sucedida de anexações pela qual, a partir do político, o consumo pôde deixar os estreitos limites com que a restrição hermética ao subsistema econômico (determinada pela soberania política) de algum modo ainda obstava a livre reprodução social da riqueza ao restringir "os movimen- 
tos espontâneos do capital". Daí que a incorporação econômica do político ou a definitiva politização do econômico (o fato de que tenha sido mudado em operador político de primeira ordem) signifique, antes de tudo, a conquista da condição privilegiada a partir da qual se deflagra uma série de anexações que pode de fato estender o domínio do consumo aos mais distantes rincões do sistema social, na medida em que o poder caracteristicamente decisório da política (em parte operado pelo mercado) oportuniza hoje um tanto das condições excepcionais necessárias à liberação sistemática dos movimentos do capital.

Abstract: Based on the reflections of Hannah Arendt and Zygmunt Bauman, this paper argues that the social system is confined to a consumer economy order, which incorporates the public sphere, giving rise to a political agenda and to an economic cooperation as a support to the enlargement of consumerism. Thus, despite the diversity of phenomena involved in a consumption order - a key issue as identification of our time - we stress that the true causes of the problem are rooted in the profound transformation of public space. Henceforth, the modern society is operated peculiarly in such a way, promoting its open extension, as well as the feature of our times.

Keywords: economy; sovereignty; Hannah Arendt; Zygmunt Bauman.

\section{REFERÊNCIAS}

ARENDT, Hannah. A condição humana. 11. ed. Rio de Janeiro: Forense Universitária, 2010.

. Entre o passado e o futuro. São Paulo: Ed. Perspectiva, 2005.

. O que é política. Rio de Janeiro: Bertrand Brasil, 2002.

- Trabalho, obra, ação. Cadernos de Ética e Filosofia Política, v. 7, p. 187-213, 2006. 
BAUMAN, Zygmunt. Vida para consumo - a transformação das pessoas em mercadorias. Rio de Janeiro: Jorge Zahar Editor, 2008.

- Capitalismo parasitário e outros temas contemporâneos. Rio de Janeiro: Jorge Zahar Editor, 2010a.

. Em busca da política. Rio de Janeiro: Jorge Zahar Editor, 2000.

- Modernidade líquida. Rio de Janeiro: Jorge Zahar Editor, 2001.

. Vida a crédito. Rio de Janeiro: Jorge Zahar Editor, $2010 \mathrm{~b}$.

CORREIA, Adriano (Org.). Hannah Arendt e a condição humana. Salvador: Quarteto Editora, 2006.

DUARTE, André. Vidas em risco. Crítica do presente em Heidegger, Arendt e Foucault. Rio de Janeiro: Forense Universitária, 2010.

LAFER, Celso. A reconstrução dos direitos humanos: um diálogo com o pensamento político de Hannah Arendt. São Paulo: Companhia das Letras, 2001. 